Editor: Dr Mark Levy Editorial Board:

Dr Chris Griffiths

Dr John Haughney

Dr Robert McKinley

Dr Paul Stephenson

Statistical Adviser:

Prof Peter Kelly

International Editorial

Adviser:

Prof Onno van Schayck

Asthma in General Practice is published on behalf of the General Practitioners In Asthma Group (GPIAG) by:

Strategic Medical Publishing Action International House, Crabtree Office Village,

Eversley Way, Thorpe,

Egham, Surrey TW20 8RY.

The GPIAG operates independently of any commercial company. However, it does receive an educational grant from Allen \& Hanburys Ltd, in order to finance the group's secretariat, its Annual Scientific Meeting, its Research Unit and this journal.

\section{ISSN 0968-039X}

Research Editor:

Christine Drewienkiewicz

Project Editor:

Jane Mortlock

The views expressed in this journal are not necessarily

those of the General

Practitioners In Asthma

Group, the publisher or Allen

\& Hanburys Ltd.

Editorial decisions are independent of commercial restraints.

(C) GPIAG Committee. All rights reserved. No part of this publication may be reproduced, stored in a retrieval system or transmitted, in any form or by any means, without the prior permission of the GPIAG Committee.

Correspondence concerning the journal should be addressed to the editor.

This journal is sent to members of the GPIAG, UK primary care faculties and NHS postgraduate centres. It is available for subscription from the publishers, Strategic Medical Publishing Ltd.

For further information about the General Practitioners In Asthma Group write to:

GPIAG Secretariat, The Medical Marketing Interface, Bath Brewery, Toll Bridge Road, Bath BA1 7DE.

\title{
New GPIAG chair in Primary Care Respiratory Medicine to be hosted at Aberdeen
}

$\mathrm{P}$ rimary care has developed into a major clinical discipline. It is an effective and economical way of delivering healthcare. Primary care physicians treat both a wide array of disease and channel more difficult or unusual problems into the hospital setting. All medical schools in the UK now have departments of general practice or primary care.

Since its inception the General Practitioners In Asthma Group (GPIAG) has aimed to revolutionise respiratory care in the UK. A major step in achieving this aim has been realised by securing funding from a consortium of pharmaceutical companies to support a Chair in Primary Care Respiratory Medicine for a period of five years. We are delighted to announce that our interview panel (Dermot Ryan and David Price, for the GPIAG, and Robert McKinley and Douglas Flemming, independent interviewers) awarded this post to the Department of General Practice and Primary Care at Aberdeen University. The professorship will be advertised and an appointment made later this year.

The professorial post will be a resource to develop pertinent, evidence-based solutions, to initiate epidemiological and clinical studies; to further develop the research network; and to explore and develop the interface between primary and secondary care. The post will support the application of evidence-based medicine by those working in primary care. By establishing this new post, the GPIAG is providing an opportunity for primary care-led research and innovation.

Respiratory diseases are major reasons for consultation in primary care. ${ }^{1}$ The primary care team manages most patients with these problems exclusively. Guidelines for the management of asthma, ${ }^{2,3} \mathrm{COPD}^{4}$ and rhinitis ${ }^{5}$ have been produced, but only a few ${ }^{3,4}$ have had input from primary care. Secondary care solutions are not always appropriate for primary care problems, one of the reasons for this new post.

The GPIAG Research Unit in Dundee continues to be responsible for important respiratory research ${ }^{6-14}$ (full bibliography on web page) and runs the group web page (http://www.gpiag-asthma.org/asthma/ GPIAG/welcome.htm). Members actively participate in national and international respiratory conferences and many have contributed significantly to the medical literature in the last 20 years. ${ }^{15}$ The group has an extensive research network of more than 250 practices. Our journal, Asthma in General Practice, publishes work relevant to primary care respiratory disease, including abstracts of work presented at our Annual Scientific Meeting.

\author{
Dr Dermot Ryan \\ Chairman, GPIAG
}

Dr David Price

Joint Research Director, GPIAG

Dr Mark Levy

Editor, Asthma in General Practice

\section{References}

1. Office of Population Censuses and Surveys. Morbidity statistics from general practice 1991/92 (MSGP4). OPCS Monitor 1994; MB5 94/1: 1-12.

2. The British Thoracic Society, The National Asthma Campaign, The Royal College of Physicians of London, et al. The British guidelines on asthma management: 1995 Review and Position Statement. Thorax 1997; 52(Suppl 1): S1-S21.

3. Scheffer A. Global strategy for asthma management and prevention: NHLBI/WHO workshop report. 1995; 95-3659: $1-176$.

4. The COPD Guidelines Group of the Standards of Care Committee of the BTS. Guidelines for the management of chronic obstructive pulmonary disease. Thorax 1997; 52: S1-S32.

5. International Rhinitis Management Working Group. International Consensus Report on the diagnosis and management of rhinitis. Allergy 1994; 49: 1-34. 6. Neville RG, Clark RC, Hoskins G, et al. on behalf of the General Practitioners In Asthma Group. National asthma attack audit 1991-2. BMJ 1993; 306: 559-62.

7. Bryce FP, Neville RG, Crombie IK, et al. Controlled trial of an audit facilitator in diagnosis and treatment of childhood asthma in general practice. $B M J 1995 ; \mathbf{3 1 0}: 838-42$

8. Neville R. Two approaches to effective asthma audit. Practitioner 1995; 239: 203-5.

9. Hoskins G, Neville RG, Smith B, et al. Do self-management plans reduce morbidity in patients with asthma? Br J Gen Pract 1996; 46: 169-71.

10. Hoskins G, Neville RG, Smith B, et al. Do self-management plans reduce morbidity in patients with asthma? Br J Gen Pract 1996; 46: 169-71.

11. Levy ML, Barnes GR, et al. Provision of primary care asthma services in the United Kingdom. Thorax 1996; 51: A28 (Abstract).

12. Neville RG, Hoskins G, Smith B, et al. Observations on the structure, process and clinical outcomes of asthma care in general practice. Br J Gen Pract 1996; 46: 583-7.

13. Hoskins G, Neville RG, Smith B, et al. on behalf of the General Practitioners In Asthma Group. Does participation in distance learning and audit improve the care of patients with acute asthma attacks? Health Bulletin 1997; 55: 150-5. 14. Neville RG, Hoskins G, Smith B, et al. How general practitioners manage acute asthma attacks. Thorax 1997; 52: 153-6.

15. Charlton I. The contribution primary care (general practice) has made to asthma care in the past twenty years. Asthma in General Practice 1997; 5: 18-20. 